\title{
Is the Papuan Harrier Circus spilonotus spilothorax a globally threatened species? Ecology, climate change threats and first population estimates from Papua New Guinea
}

\author{
ROBERT E. SIMMONS and LEO A.T. LEGRA
}

\section{Summary}

We undertook a 3-week expedition to Papua New Guinea in April-May 2007 to assess the breeding, threats and population densities of the Papuan Harrier Circus spilonotus spilothorax and to determine a first global population estimate for this almost entirely unknown species. Two of the first nests known were discovered in April 2007 with three chicks each, in the eastern lowlands, in rank grass and reeds. The melanistic form of this subspecies was more common in the lowlands $\left(<_{1,500} \mathrm{~m}\right.$ a.s.l $)$ than in the highlands, but interbreeding of this and the typical form occurred in the lowlands. Movements of identifiable individuals through two highland grasslands indicated up to eight birds per day on passage, corroborating local knowledge that other raptors move into the highlands at the start of the dry season (April). Linear road counts indicated no harriers in the wooded highlands but up to 2.9 harriers $10 \mathrm{~km}^{-1}$ in lowland grasslands. Area counts gave an average of 6.5 harriers $100 \mathrm{~km}^{-2}$ in the grasslands and a breeding density of 1.21 nests $100 \mathrm{~km}^{-2}$. Given that preferred grassland and swamp habitat comprises c. $7 \%$ of the forest-dominated island of New Guinea, the global Papuan Harrier population can be no more than $c$. 3,60o birds and $c$. 740 breeding pairs. Wildfires peaked at 38 per month in the study area, occur throughout the dry season, and led to the loss of both nests. This suggests that many nests and prey may be lost at critical times and burning may be ultimately detrimental for the species. Grassland fires throughout Indonesia and Papua New Guinea are increasing with climatic warming and ENSO events, so we suggest that the Papuan Harrier may warrant a 'Vulnerable' conservation ranking due to small total population size and an accelerated reduction in habitat quality due to ongoing climate change.

\section{Introduction}

The endemic-rich island of New Guinea (Heads 2002) holds 31 species of diurnal raptor including seven species of Accipitrine hawks (Diamond 1985, Beehler et al. 1986) and the large but elusive New Guinea Harpy Eagle Harpyopsis novaeguineae (Legra 2005). Almost all are unstudied. The paucity of knowledge has led to some confusion regarding the only resident harrier there - the Papuan Harrier Circus spilonotus spilothorax. Despite being a resident on an island full of endemic vertebrates (Beehler et al. 1986, Coates 1985, Flannery 1995), it is currently treated by most authorities (Ferguson-Lees and Christie 2001, BirdLife International 2004) as a subspecies of Eastern Marsh Harrier Circus spilonotus, a bird that currently never visits the island. It is said to vary from rare to locally common in grasslands and swampy areas with two colour morphs (dark brown and typical: Coates and Peckover 2001) making it easily confused with the 
Australasian Swamp Harrier Circus approximans which occasionally visits the island (Beehler et al. 1986, Coates and Peckover 2001).

Some authors have suggested that the Papuan Harrier be treated as a full species based on plumage differences with the Eastern Marsh Harrier, the lack of immigration of this species from the north, and its resident status in New Guinea (Simmons 2000, Coates and Peckover 2001). This proposal has been rejected by BirdLife International whose policy is to require published evidence from DNA or morphological data to change accepted wisdom (http://www.birdlife.org/ datazone/species/taxonomy.html 2008). For these reasons we undertook an expedition to Papua

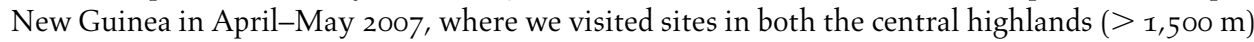
and lowlands in the east of the country to study breeding activity, movements, and habitat preferences of breeding birds, and estimate overall densities of all harriers. To resolve the subspecies debate we additionally collected tissue (feathers and blood) samples for DNA analysis. The first genetic results are still pending (M. Wink and R. Simmons in Unpubl. data), but we assume full species status (based on the previous arguments) in order to take a precautionary principle approach to give this bird a first-order global conservation ranking. Our results represent the first systematic efforts to understand the ecology of Papuan Harriers, a species for which only one nest has previously been found (Campbell pers. comm. in Coates 1985) and whose lack of current conservation ranking (BirdLife International 2008) may jeopardize its future welfare.

\section{Methods and Study Area}

New Guinea is a wooded tropical island some 2,00 km long, lying $5^{-6^{\circ}}$ south of the equator just north of Australia, with high annual rainfall varying from 1.2 to $10 \mathrm{~m}_{\text {year }}{ }^{-1}$ (McAlpine et al. 1983, Beehler et al. 1986). Politically, the island comprises Irian Jaya (or West Papua) in the western half and Papua New Guinea (PNG) in the east. About $93 \%$ of the island is wooded with the remainder comprising lowland swamp, highland grassland and cool alpine areas (Beehler et al. 1986, S. Haberle in litt.). Highlands, defined as land above 1,500 m (Whitmore 1984), account for about $14 \%$ of the surface area (Beehler et al. 1986). Rainfall is variable from region to region but the highlands here receive about $1.85-6.4 \mathrm{~m}$ of rain in the wetter months of November through March (McAlpine et al. 1983, Symes and Marsden 2005).

During a three-week study period (24 April - 17 May 2007) three study areas in the eastern part of PNG were searched intensively for foraging and breeding birds; two in the highlands (Goroka 6 ${ }^{\circ} 5^{\prime} \mathrm{S}, 145^{\circ} 25^{\prime} \mathrm{E}$; $1,500 \mathrm{~m}$; and Mt Hagen $5^{\circ} 46^{\prime} \mathrm{S}$, $144^{\circ} 17^{\prime} \mathrm{E} ; 1800-2,800 \mathrm{~m}$ ), and one in the lowlands - the Markham and Ramu Valleys (Figure I) at 400-500 m. These were initially chosen based on reports of one nest from Mt Hagen and multiple sightings from the lowland valleys (Coates 1985). We have used harrier densities gathered here to extrapolate to other parts of the island with appropriate habitat to give a preliminary population estimate. Intervening areas were searched by car but most effort was expended on following harriers at the two large airstrips in the highlands - areas of grassland and low bush, 2.1-2.3 km long and undisturbed by the otherwise dense populations of people in the surrounding towns. Intervening highlands were characterized by dense woodland with some areas cleared for small subsistence gardens (Marsden et al. 2006), or by annual fires and dominated by open grassland. During the dry season of highland PNG (April-September), anthropogenic grassland burning is very common in both the highlands and the lowland Markham and Ramu Valleys (pers obs.). Such fires are not new, and occur most commonly during drought associated with ENSO (El NiñoSouthern Oscillation) climatic events (Johns 1989, Haberle et al. 2001).

The fertile Markham and Ramu valleys lie either side of Watarais $\left(5^{\circ} 57^{\prime} \mathrm{S}, 145^{\circ} 54^{\prime} \mathrm{E}\right)$, with the Markham River flowing north-east from here, and the Ramu River flowing north-west. The Ramu Valley supports extensive sugar-cane plantation, emerging oil palm plantations and some fallow fields (Figure 1). The Markham valley is dominated by Imperata cylindrical grassland interspersed with subsistence gardens, and some trees such as Coconut Palms Cocos nucifera. Rainfall is 1,954 mm per annum and soil fertility high but declining (Hartemink 2003). Human 


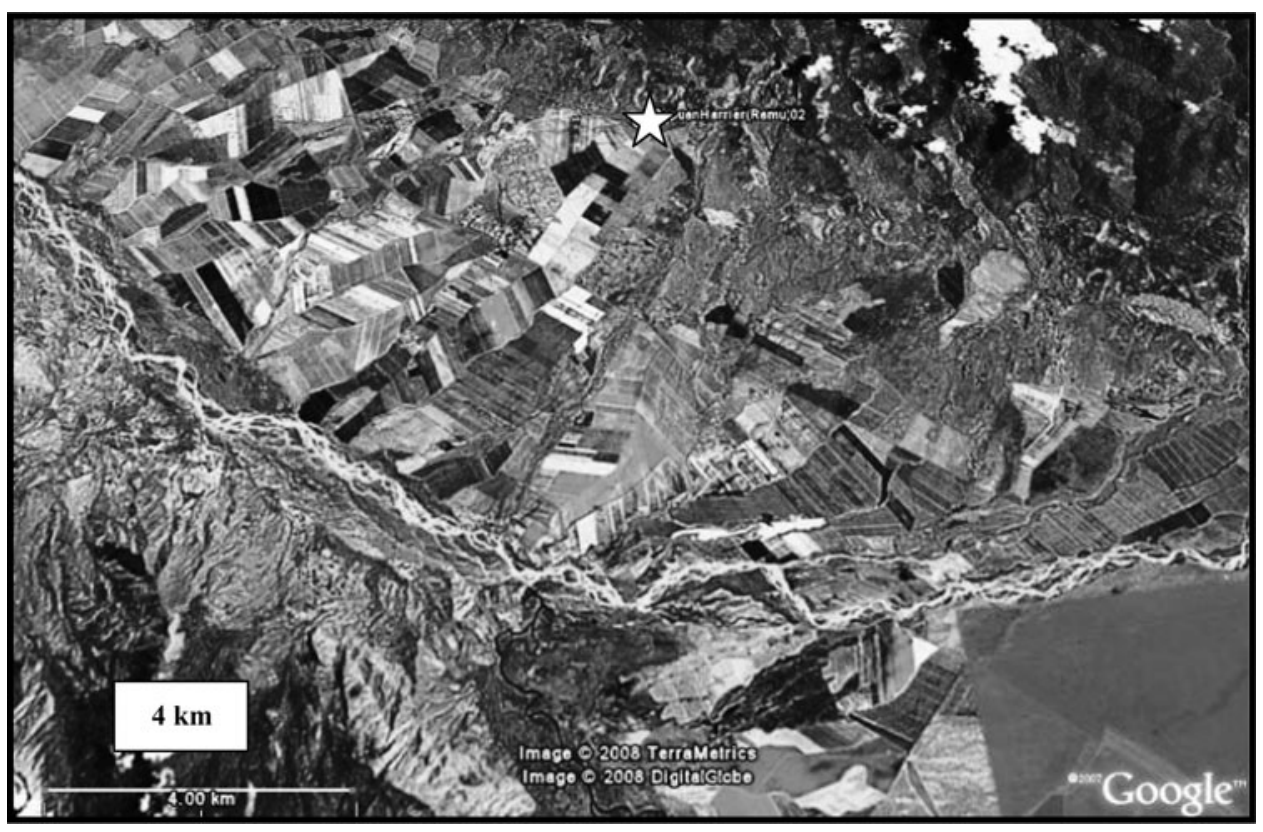

Figure 1. A Google Earth ${ }^{\mathrm{TM}}$ image of the Papuan Harrier nest site No. 2 (star) in the Ramu Valley Papua New Guinea. The image shows the intensive sugar-cane farming in the Ramu Valley ( $\left.5_{5}^{\circ} 57.045^{\prime}, E_{145}{ }^{\circ} 54.330^{\prime}\right)$, the Ramu River to the south and already burned cane field. Further dry-season burning reduced the grassland area available and this nest was lost to fire.

population density in both valleys is low but widespread and concentrated around traditional villages (Fig. I).

A combination of raptor road counts and fixed-point observations were employed to determine the density and movements of individual harriers through grassland areas where they occurred. For estimates of harrier breeding density a transect width of $2 \times 1.5 \mathrm{~km}$ was chosen in the grassland valleys. This area was conservatively chosen based on the discovery of a breeding male observed at slightly greater distance of $1.9 \mathrm{~km}$ that led to the second nest. A total transect length of $50 \mathrm{~km}$ traversed slowly by vehicle over three days in this valley gave a transect area of $150 \mathrm{~km}^{2}$. Densities of harriers and their nests were calculated from this. Other road surveys are given as linear densities of birds per $10 \mathrm{~km}$. Typical road counts (Young et al. 2003) covering over $600 \mathrm{~km}$ were undertaken with two observers travelling $\leq 80 \mathrm{~km} \mathrm{~h}^{-1}$ along major routes within the highlands (comprising grasslands and woodland habitat with numerous small subsistence farms), between the highlands and lowlands (comprising hill forest habitat), and over shorter routes within the two valleys (unburned open grasslands with little agriculture).

Individual birds were identified using a combination of digital photographs, video clips and pencil sketches. The diversity provided by melanism, pale subadult plumage, yellow- vs browneyed birds and marked differences between adult males (black, grey and white plumage) and adult females (brown streaked plumage: Coates and Peckover 2001) allowed us to identify individual birds as resident or on passage.

All observations were undertaken with $8.5 \mathrm{x}$ binoculars and nest positions were marked using a Garmin II Global Positioning System accurate to about $10 \mathrm{~m}$. Digital photographs and video clips were captured with a Canon Powershot $S_{3}$ with $12 x$ optical magnification and bird images were downloaded onto a laptop computer for scrutiny of colours and distinguishing marks. 
Nests were found by following prey-carrying males from a moving vehicle or an elevated hillside position. Prey delivered via a food pass to breeding females and taken to the nest revealed their position (Simmons 2000). Other areas over which male and female harriers were performing aerial displays were also observed until food was delivered or no further breeding activity occurred.

To quantify the scale of burning, NASA images on the Modis website, supplied by University of Maryland (http://maps.geog.umd.edu/firms/maps.asp) were consulted. Images of fire scars during the initial surveys (April-May 2007) and throughout the dry season (April-September) were downloaded.

\section{Results}

More melanistic (dark brown) adults than typically-plumaged harriers occurred in the lowlands than above $1,500 \mathrm{~m}$ a.s.l. In total, six of 21 adult and subadult birds $(29 \%)$ were classed as melanistic in the lowlands, while only one of 15 individually identified birds $(7 \%)$ was classified as such in the highlands. Thus, while melanism accounted for $19.4 \%$ of 36 individually recognized Papuan Harriers, the typical adult grey (male) and streaked brown (female) were the commonest plumage types.

\section{Movements and harrier densities}

No harriers were seen in grassland valleys around Goroka but birds were present at the less disturbed airports supporting grasses and few bushes (Table 1). At Goroka airstrip, where a maximum of three different harriers occurred at any time, no individuals appeared to stay for more than two days. In five days of observation, covering $11 \mathrm{~h} 20 \mathrm{~min}$ at Goroka airstrip, three birds declined to no birds, then one immature bird was recorded on the last day. At Mt Hagen airport, five days observation (2-7 May) covering 27 h 50 min, a maximum of 2-9 harriers per day passed through and foraged over the wet grassland surrounds (Table 1 ). As far as we could tell only one of these birds stayed for more than two days - a dark adult female displaying and exhibiting typical harrier pre-breeding behaviour. A small roost of $4-5$ birds was apparent in the I $\mathrm{m}$ high grass adjacent to the second airstrip; birds entered this area about $20 \mathrm{~min}$ before sunset (17h40) and had left before we arrived the following morning shortly after sunrise.

No harriers were observed in $44 \mathrm{I} \mathrm{km}$ of wooded hill forest areas of the highlands, but other raptors were common including Brahminy Kite Haliastur indus, Whistling Kite H. sphenurus, Black Kite Milvus migrans, Variable Goshawk Accipiter novaehollandiae, Collared Sparrowhawk A. cirrhocephalus, Brown Falcon Falco berigora, Black-winged Kite Elanus caeruleus and Whitebellied Sea Eagle Haliaeetus leucogaster (Table 2). Papuan Harriers were encountered again in the lowland grasslands in the Ramu and Markham Valleys below $500 \mathrm{~m}$. Linear densities of

Table 1. Number of individually recognized Papuan Harriers seen passing through Mt Hagen Airport, Eastern Highlands, 2-7 May 2007.

\begin{tabular}{lllllll}
\hline $\begin{array}{l}\text { DATE } \\
\text { (h observed) }\end{array}$ & $\begin{array}{l}\text { Adult } \\
\text { Male }\end{array}$ & $\begin{array}{l}\text { Adult } \\
\text { Female }\end{array}$ & $\begin{array}{l}\text { Sub-adult } \\
\text { male }\end{array}$ & $\begin{array}{l}\text { Sub-adult } \\
\text { female }\end{array}$ & Juv & $\begin{array}{l}\text { Total number } \\
\text { of birds }\end{array}$ \\
\hline 2 May (6.5) & 2 & 1 & $3-5$ & - & 1 & $7-9$ \\
3 May (9.3) & - & 2 & 1 & - & 1 & $4^{*}$ \\
4 May (7.0) & - & 2 & 4 & 1 & 1 & 8 \\
6 May (3.0) & - & & 1 & - & - & 2 \\
7 May (2.0) & - & 2 & 1 & - & 3 \\
\hline
\end{tabular}

* excludes small roost of $4-5$ birds active at airport in which sexes difficult to distinguish 
Table 2. Harriers and other raptor species encountered in highland and lowland areas of Eastern Papua New Guinea during road surveys between 26 April and 13 May 2007. Papuan Harriers densities are given as birds $10 \mathrm{~km}^{-1}$ traversed and the lowland sites are the last 4 rows.

\begin{tabular}{|c|c|c|c|c|c|}
\hline Location & Habitat & $\begin{array}{l}\text { Harriers } \\
\text { seen }\end{array}$ & $\begin{array}{l}\mathrm{Km} \\
\text { driven }\end{array}$ & $\begin{array}{l}\text { Harriers } \\
\text { 10 } \mathrm{km}^{-1}\end{array}$ & $\begin{array}{l}\text { Other raptors } \\
\text { seen }\end{array}$ \\
\hline Bena Valley & $\begin{array}{l}\text { mixed grass/ } \\
\text { woodland/gardens }\end{array}$ & o & 24 & 0.0 & Black Kite 14 \\
\hline Aseroka Valley & $\begin{array}{l}\text { mixed grass/ } \\
\text { woodland/gardens }\end{array}$ & o & 15 & 0.0 & Black Kite 1 \\
\hline $\begin{array}{l}\text { Goroka to } \\
\text { Mt Hagen }\end{array}$ & Hill forest & $2^{*}$ & 183 & 0.1 & $\begin{array}{l}\text { Black Kite } 18 \\
\text { Whistling Kite } 2 \\
\text { Brahminy Kite } 2 \\
\text { Sparrowhawk sp } 2\end{array}$ \\
\hline $\begin{array}{l}\text { Mt Hagen to } \\
\text { Kumul Lodge }\end{array}$ & Hill forest & o & 66 & 0.0 & $\begin{array}{l}\text { Black Kite } 5 \\
\text { Brahminy Kite } 1\end{array}$ \\
\hline $\begin{array}{l}\text { Kumul Lodge to } \\
\text { Mt Hagen }\end{array}$ & Hill forest & o & 42 & 0.0 & $\begin{array}{l}\text { Black Kite } 14 \\
\text { Variable Goshawk } 2\end{array}$ \\
\hline $\begin{array}{l}\text { Goroka to } \\
\text { Kassam Pass }\end{array}$ & Hill forest & o & 150 & 0.0 & Black Kite 25 \\
\hline Ramu Valley & $\begin{array}{l}\text { Lowland grassland/ } \\
\text { Sugar cane }\end{array}$ & 3 & 34 & 0.88 & $\begin{array}{l}\text { Sparrowhawk sp. } 1 \\
\text { Black Kite } 40 \\
\text { Brown Falcon } 2\end{array}$ \\
\hline Ramu Valley & $\begin{array}{l}\text { Lowland grassland/ } \\
\text { Sugar cane }\end{array}$ & 5 & 29 & 1.72 & $\begin{array}{l}\text { Black Kite } 18 \\
\text { Whistling Kite } 1 \\
\text { Brown Falcon } 3\end{array}$ \\
\hline Markham Valley & $\begin{array}{l}\text { Lowland grassland/ } \\
\text { Sugar cane }\end{array}$ & 4 & 14 & 2.86 & $\begin{array}{l}\text { Black Kite } 4 \\
\text { Black-winged Kite } 1\end{array}$ \\
\hline $\begin{array}{l}\text { Ramu + Markham } \\
\text { Valley }\end{array}$ & $\begin{array}{l}\text { Lowland grassland/ } \\
\text { Sugar cane }\end{array}$ & 11 & 50 & 2.20 & $\begin{array}{l}\text { Black Kite } 115 \\
\text { White-bellied Sea Eagle } 1 \\
\text { Collared Sparrowhawk } 1\end{array}$ \\
\hline
\end{tabular}

$*_{2}$ harriers observed only in the last $10 \mathrm{~km}$ of valley grassland

harriers there varied between 0.9 and 2.9 birds $10 \mathrm{~km}^{-1}$ (Table 2). Birds foraged over semiburned grassland and were attracted to the burning areas, alongside numerous Black Kites. Within an estimated area of $150 \mathrm{~km}^{2}$ a maximum of 11 harriers were seen from the road per day. The average density of birds seen over 3 days was 6.5 harriers $100 \mathrm{~km}^{-2}$ with a range from $4 \cdot 6-7 \cdot 3$ harriers $100 \mathrm{~km}^{-2}$.

\section{Breeding density and first estimate of harrier population size}

Given that two active harrier nests ( $35 \mathrm{~km}$ apart) occurred within the same area, the minimum estimated nesting density was one nest $82.5 \mathrm{~km}^{-2}$ (or 1.33 active nests $100 \mathrm{~km}^{-2}$ ). The potential nest density, given that 4 nests were suspected (pairs calling and intense aerial displaying by two males) within the same area, gives an extrapolated nest density of 1 nest $41.25 \mathrm{~km}^{-2}$ (or 2.67 nests $100 \mathrm{~km}^{-2}$ ).

We can use the Papuan Harrier densities to provide a first estimate of the world population size of this species. About $7 \%$ of the island of New Guinea (792,500 km²; National Geographic 1990) is potential harrier habitat of grassland and swamp (Beehler et al. 1986, S. Haberle in litt.). Given that the harriers do not occur on any of the surrounding archipelagos of New Britain, New Ireland or Bougainville (Coates and Peckover 2001), and forage but are unlikely to breed in intense agricultural areas because of disturbance, there is about $55,475 \mathrm{~km}^{2}$ of suitable habitat 
for Papuan Harriers. At a mean density of 6.5 birds $100 \mathrm{~km}^{-2}$ (range $4.6-7.3$ birds $100 \mathrm{~km}^{-2}$ ), we estimate a total population across the island of New Guinea to be 3,606 birds. Given the range in field densities, the population size varies from 2,552 to 4,050 birds.

Using the known nesting density, estimated at 1.33 nests $100 \mathrm{~km}^{-2}$ and the same assumptions regarding suitable habitat available to Papuan Harriers, the maximum estimate of breeders on the island of New Guinea is about 738 nests. Using potential nests $\left(2.67\right.$ nests $\left.100 \mathrm{~km}^{-2}\right)$ the estimated number of pairs on New Guinea is 1,481. Both are upper estimates given that the densities were derived from grassland valley habitat considered ideal for breeding birds.

\section{Breeding activity}

Two nests, both in the lowland valley (404 and $510 \mathrm{~m}$ ), were found following male to female prey transfers. Nest 1 was in a dense and extensive stand of rank grass and reeds, on damp ground without standing water, $c$ 180 m off a tar road at the west end of the Markham Valley. Villagers within $1 \mathrm{~km}$ of the nest were unaware of the birds' presence. Nest 2 in the Ramu Valley was built in a river flood plain adjacent to sugar cane fields, on damp ground (Figure 1). Both nests were built adjacent to reed clumps, about $1 \mathrm{~m}$ high, that stood slightly above the surrounding grasses. This offered complete shade to the nest contents, in an area that regularly experienced day-time temperatures exceeding $30^{\circ} \mathrm{C}$.

Both nests had three small downy white chicks. Given a mean incubation period of about 31 days for harriers (Simmons 2000), the first egg in Nest 1 was estimated to have appeared on 6 April, and Nest 2 is estimated to have started on 2 April, the start of the dry season.

\section{Breeding success and grassland burning}

Both nests were revisited in mid June, four weeks after discovery, to check for success. Nest 1 , in a subsistence agriculture area, was destroyed by a fire that also burned the surrounding area (P. Limu pers. obs.). Nest 2 in the Markham River floodplain was likewise destroyed by fire that swept the area (L. L. pers. obs.). Thus neither nest was successful nor could growth of the nestling harriers be monitored. The distance between the two nests was $35.1 \mathrm{~km}$.

The lowland areas where the nests were found were dominated by grassland and sugar cane. Both sides of the valley were steep-sided grassy hills topped by montane rainforest. All of these grasslands were burned or in the process of burning as we left the area in mid May. Local knowledge indicates that all grasslands and old sugar cane fields in this valley are burned before the end of the dry season (P. Limu pers. comm.).

To quantify the scale of burning, fire scars captured in Modis-NASA images from April-May 2007 and throughout the dry season (April-September) were magnified and counted. This indicated that the Ramu and Markham valleys were particular hotspots of fire activity beginning in April $(n=1)$, increasing in May (21 fires), reaching a peak in June ( 38 fires), and declining to 24 fires in August. By September there were no fires (Figure 2). The total number of individual scars in this 6-month period was 108 in the $150 \mathrm{~km}^{2}$ area, an average of 18 per month.

\section{Discussion}

These data represent the first systematic investigation of the Papuan Harrier of New Guinea and the first detailed evidence of breeding. Our most important results indicate that Papuan Harriers (i) occur commonly in two plumage forms - a rarer dark brown one and the more typical grey and white (male) birds which interbreed; (ii) the bird is confirmed as breeding in the dry season in damp grasslands and floodplains; and (iii) the first estimated world population size of this island endemic gives a small population of about 3,600 birds and 740 breeding pairs. We suggest below that the small population size and the timing and extent of grassland burning in its strongholds 


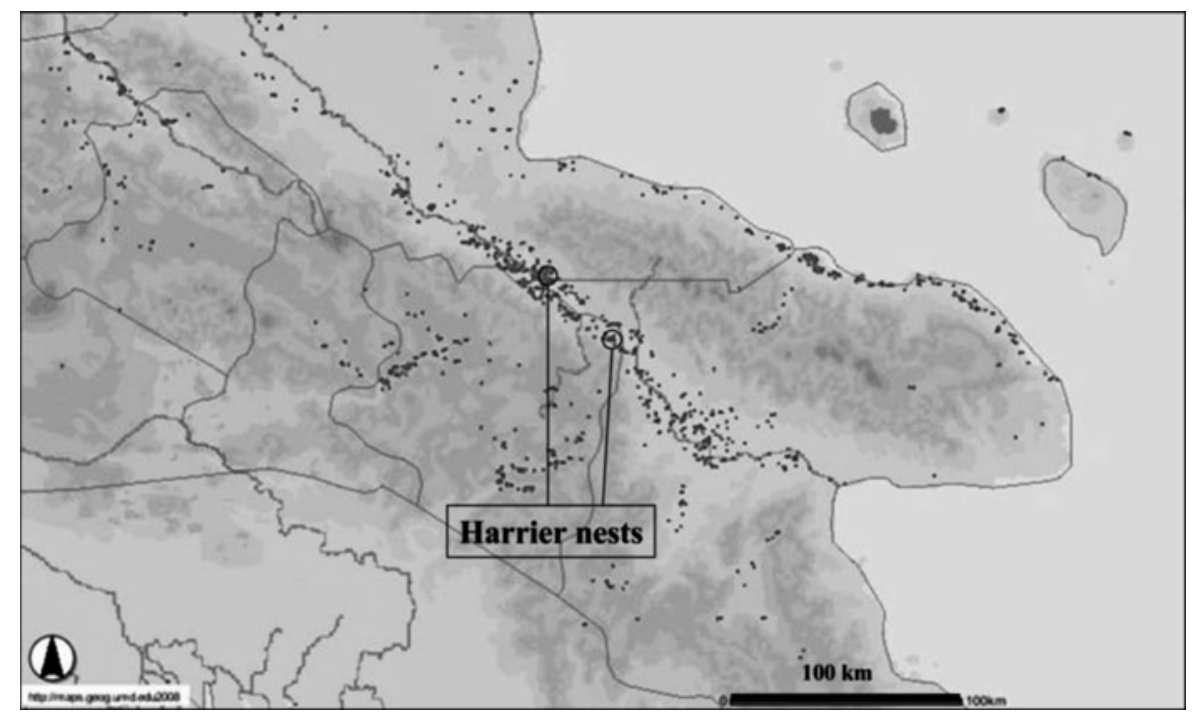

Figure 2. Fire scars in north-eastern Papua New Guinea, recorded from space from AprilDecember 2007. The position of the two Papuan Harrier nests is indicated. The frequency of fires in the $150 \mathrm{~km}^{2}$ study area of the Ramu and Markham valleys in this period was 17 per month reaching a peak of 38 fires in June. (Modis and NASA images, downloaded from http:// maps.geog.umd.edu/website/Activefire_html for South East Asia)

are large enough threats for this species to warrant a 'Vulnerable' conservation ranking. A global conservation ranking is, however, only possible once the status of this species has been verified (M. Wink, R.E. Simmons unpubl. data) and a suspected rate of decline is quantified or suspected. We quantify the (increasing) frequency of fire as the most likely threat to breeding success in both present day and future PNG.

\section{Movements in relation to rainy seasons}

The rapid turnover of individual Papuan Harriers through both highland airports suggested that birds were on passage to other areas. We were unable to follow individuals away from the airports but discussions with knowledgeable residents in highland villages near the town of Goroka indicated that raptors entered habitat around their villages during April-September, the dry season (K Yombu pers. obs.). This is corroborated by observations from swamp areas in the southern lowlands around Kurik (Figure 3) where Hoogerwerf (1964) observed that Papuan Harriers were absent from May-September (dry season) but present in all other months over four years. It is also notable that breeding seasons of other birds of prey in PNG coincide with the dry season (Bell 1982). This is understandable given the amount of rain (2-10 $\mathrm{m}$ per annum in the highlands: McAlpine et al. 1983, Symes and Marsden 2005) which may prevent raptors from breeding or foraging for prey in heavy to torrential rain. The observation that breeding of most insectivores, frugivores and mixed feeders in the Eastern highlands occurs in the dry or early-wet season (Symes and Marsden 2005), means that harriers may also have an additional prey source of young birds, given that avian prey remains were relatively common in the diet (unpubl. data). Our observations of Black Kite, Black-winged Kite and Brown Falcon copulating and nest building in early May in the Markham Valley corroborate this. Breeding of the Madagascar Harrier Circus macrosceles in the dry season is similarly observed in the high rainfall 


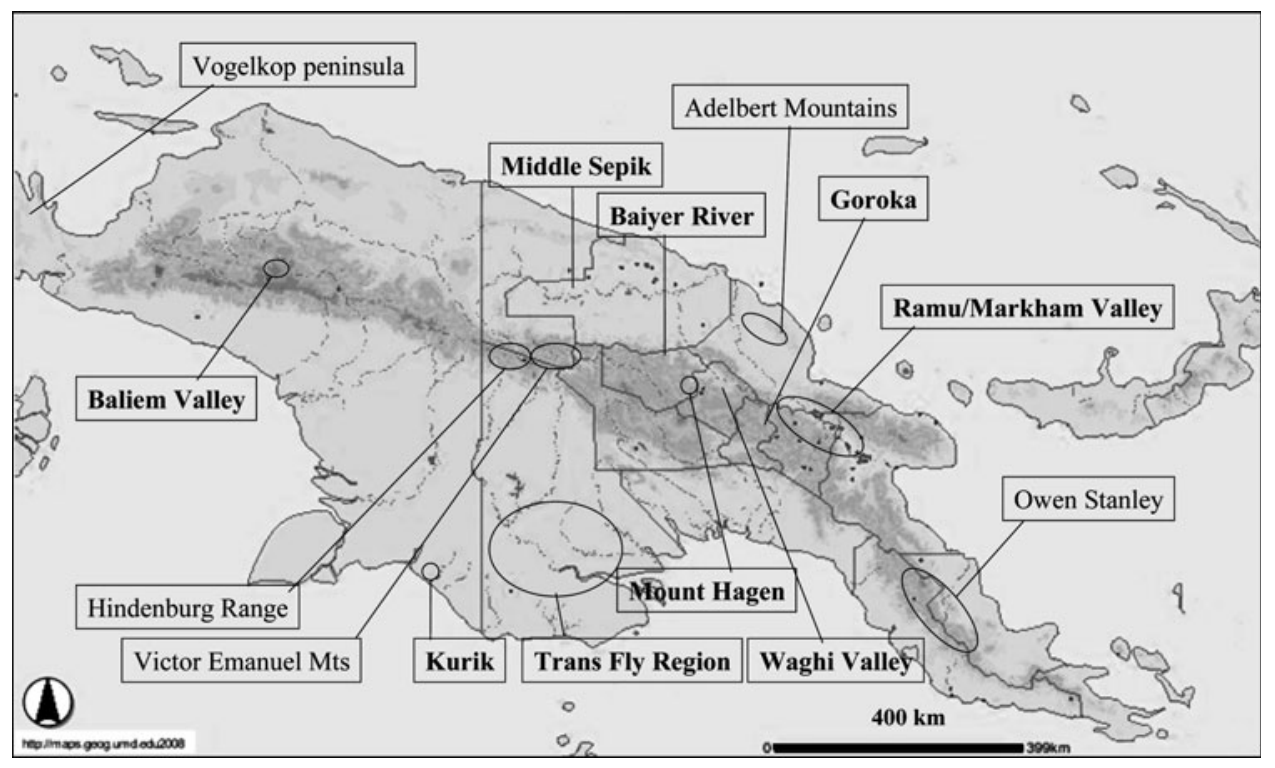

Figure 3. The island of New Guinea indicating places mentioned in the text including the two main study sites (Ramu/Markham Valley and Mount Hagen-Goroka highlands) and other regions where Papuan Harriers have been found (in bold) or assessed and not found.

regions of Madagascar (Rene de Roland et al. 2004) and wildfires also occur at these times (Rene de Roland et al. unpubl. data). Thus we assume that at least some raptors are moving from low ground into the highlands in order to breed. While we did not find any breeding of harriers in the highlands, a displaying and calling female Papuan Harrier that remained for over two days at Mt Hagen airstrip suggested breeding was imminent at the end of April. Brown Falcon and Brahminy Kite moving through Yabiufa Village (2,000 m) near Goroka suggest that the movement is not confined to harriers.

\section{Population size, wildfire and global conservation status}

The Papuan Harrier was found to be locally common but transient in two highland grasslands above $1,500 \mathrm{~m}$. As expected, the first road counts for PNG recorded no harriers but several other woodland raptors in the hill forest habitats. Thus reduced visibility in dense woodland cannot account for the lack of harriers. They were frequently recorded in the lowland grasslands of the Markham Valley. While nesting densities of 1.33 nest $100 \mathrm{~km}^{-2}$ are the first recorded for the Papuan Harrier they require confirmation with larger samples. Densities averaging 6.5 harriers $100 \mathrm{~km}^{-2}$ allow us a first opportunity to estimate the global population given that birds have been reported from other suitable lowland habitats such as the Trans Fly region and Gali Ephata marsh (near Kurik) in southern Papua New Guinea (Figure 3), the Middle Sepik of northern New Guinea and the Baiyer River region (Hoogerwerf 1964, Coates 1985, B. Coates pers. comm., P. Gregory pers. comm.). A few highland grasslands also hold harriers around the Baliem Valley (at 3,00o m), the Tari Gap and Wahgi Valley (Mayr and Gilliard 1954, Coates 1985, Hornbuckle 1997, P. Gregory pers. comm.) but no density estimates have been reported. Our own observations at high altitude suggest lower densities and few resident birds, possibly because of the low diversity of small mammals apparent in such grasslands (K. Aplin in litt.). This corroborates 
previous ornithological expeditions to highlands such as the Adelberts, Owen Stanley, Victor Emanuel, Hindenburg Mountains and the far western Vogelkop peninsula (Figure 3) where no harriers were reported by past and present ornithological expeditions (Gilliard and Lecroy 1961, 1967, Coates 1985, P. Gregory pers. comm., B. Beehler pers. comm). Therefore, the world population figure of 3,606 birds (range 2,552-4,050 birds) is probably an upper estimate. A second reason for believing this is close to maximum comes from the fact that density estimates were derived from the Markham and Ramu Valleys, which yielded more long-term sightings prior to this study than anywhere else in Papua New Guinea (Coates 1985). Density estimates from other parts of New Guinea, particularly lowland swamps (B Coates pers. comm.), are required to corroborate this first estimate. Dividing the island into suitable habitat blocks and completely or randomly searching such habitat are two proven methods for surveying difficult species such as harriers (Bretagnolle et al. 2000, Curtis et al. 2004).

Given these caveats and assuming the population estimate is accurate to within a thousand birds, what does this mean for the Papuan Harrier global conservation ranking? Species numbering $<10,000$ mature individuals that also show declines inferred or known to be at least 10\% over 10 years or two generations (whichever is longer), are classified as 'Vulnerable' (Birdlife International 2008). We suggest that this species may warrant a 'Vulnerable' ranking given the low number of birds estimated for New Guinea, and the direct threat posed by grassland wildfire to these ground-nesting birds and their prey.

Widespread grassland burning in the Ramu and Markham valleys resulted in both nests being lost to fires. Given that the entire valley and the grassy hillsides are completely burned by the end of the season (P. Limu pers. comm.), other nests also have a high likelihood of failure. Villagers frequently start fires to isolate terrestrial mammals such as Ground Cuscus (or Possum) Phalanger gymnotis in the unburned patches, which are subsequently killed and eaten. Thus, these fires are an annual event, starting in the dry season and are anthropogenically driven. Moreover, increasing fire frequency may have already made the grasslands inhospitable for small mammals because they are reported to be of low diversity in the grasslands (K Aplin in litt. 2007). Satellite images not only corroborate the extent of fires but their frequency throughout the dry season (Figure 2). Assessed month by month, fire scars revealed a peak in June just after the harriers started breeding and at least 108 separate fires in the $150 \mathrm{~km}^{2}$ study area. Cloud cover often obscures fires in Papua New Guinea so this is a minimum estimate of frequency. So both early and late nests are equally likely to be destroyed by fires in any remaining dense vegetation, which breeding harriers prefer (Baker-Gabb 1986, Rene de Roland et al. 2004, Simmons 2005). Despite the potentially increased area of grasslands generated from widespread fire use in the last 5,000 years (Haberle et al. 2001), the timing and extent of burning are both detrimental to ground-nesting harriers. Fires have been detected for at least 32,500 yr BP (before present) in charcoal deposits in lake sediments (Haberle 1998, Haberle et al. 2001). Grasslands favoured by harriers were promoted by a $5^{\circ} \mathrm{C}$ cooler climate in PNG prior to 17,000 BP but were reduced as wetter weather promoted increased forest cover over PNG between 17,000 and 9,000 yr BP (Haberle et al. 2001). A greater frequency of fire in forested areas from c. 7,000 yr BP to present is associated with increased climatic instability and increased agricultural activity (Haberle et al. 2001). Both have increased the amount of relatively low diversity grassland in highland PNG (Hope and Tulip 1994, Haberle et al. 2001, Haberle 2007), and may have benefited at least some bird species through range expansions (Diamond 1972). These studies point to a waxing and waning of open areas favoured by harriers, dependent upon climate and modern man. That man is responsible for many present-day fires is apparent from palynological studies around Mt Wilhelm, Papua New Guinea's highest peak, indicating that forest clearance through fire started 700 years ago and the main period of clearance was about 300 years ago (Corlett 1984, 1987). That reforestation can occur in as quickly as 20 years in the absence of fire (Corlett 1987) means that grasslands must be frequently burned to remain as such (Corlett 1987, Haberle et al. 2001). If harriers consistently time their breeding to the start of the dry season, their ground nests will always be susceptible to grass fires. We predict, but cannot quantify, that over 
10 years the population may decrease at 10\% per year; a decrease promoted by increasing human populations and accelerated by climate warming.

The evidence that the New Guinea climate is becoming more fire-prone comes from regional research and local knowledge. Fires are becoming more frequent and destructive in the lowland rainforest of Indonesia; in 1997 extensive fires $\left(50,000 \mathrm{~km}^{2}\right)$ swept through Irian Jaya (west Papua), and Sumatra causing widespread ecological damage to rainforest there (Kinnaird and O'Brien 1998). More importantly, recent research has shown that the frequency of wildfires is positively correlated with El Niño events that bring dry conditions to southern hemisphere countries (Haberle et al. 2001, Westerling et al. 2006, Kinnaird et al. 2007). Because El Niño events are becoming more frequent with climate change (Timmerman et al. 1999), logically fire frequency will also increase. This is also reflected locally in changing agricultural coffee crops in the Eastern New Guinea highlands that are now possible twice per year because they require dry conditions for the picking and drying of coffee beans. Less than a decade ago this was not possible because of higher rainfall (K. Yombu pers. comm.). Both results point towards an expected greater frequency and magnitude of wildfires throughout New Guinea because of global warming. Any Papuan Harriers breeding in the dry season will almost certainly experience reduced success, as will many other grassland species.

Legra et al. (2008) have also shown a secondary consequence of global warming on Papua New Guinea - sea level rise inundating low-lying regions. They report that with a $1 \mathrm{~m}$ rise in sea level, 21\% of the Trans Fly region in southwestern Papua New Guinea will be inundated, flooding grasslands and fresh water swamps. This will decrease further the area available to breeding and foraging Papuan Harriers in PNG.

Of other threats, direct human persecution appears to be negligible based on the lack of fear shown by foraging birds around gardens and traditional villages in the highlands, and airports and modern buildings elsewhere in the highlands. The lack of animosity or recognition of the Papuan Harrier by local villagers suggests that there is no direct human persecution of this species. Poison baiting for Rats (Rattus spp.) within oil palm plantations in the Ramu Valley (P. Limu pers. comm.) is localized and harriers were not seen foraging within these habitats.

Further study is required of this and other raptors and grassland species in New Guinea in a landscape where the forest birds of paradise have always taken research precedence (Mack and Wright 1996). Research should focus on understanding the dynamic between the double-edged effects of fire opening up forested landscapes for grassland species, and the costs to biodiversity caused by burning too frequently at the start of many species' breeding season.

\section{Acknowledgements}

We are indebted to J. Robbins OBE of the National Research Institute of Papua New Guinea for facilitating research and collecting permits from the Department of Environment and Conservation and to Prof L. Hill for affiliation to the University of Papua New Guinea. J. and M. Simmons and D. Scott proved excellent field assistants.

The Wildlife Conservation Society in Goroka, Eastern Highlands, provided field transport and logistical support, and we are indebted to A. Mack, J. Kol and driver O. Oneka. Accommodation and logistical support was generously provided by P. and B. Ellis at the Goroka Primary School, and advice and transport provided by P. Limu of Ramu Sugar Ltd. K. Yombu and M. Poliaka guided R.E.S. through the highland grasslands and R. Topiso and R. Palia allowed us access to the Mt Hagen airstrip.

This expedition was funded by Natural Research Limited, UK, The Acopian Centre for Conservation Learning at Hawk Mountain Sanctuary, USA, and University of Heidelberg, Germany. Special thanks to Drs R. Tingay, K. Bildstein and Prof M. Wink for ensuring the success of the project. Dr P. Barnard and J. Simmons helped with logistics, Dr C. Seymour with statistics, 
Dr K. Aplin with mammal identification, Dr B. Beehler with bird species identification and he, B. Coates, P. Gregory, S. Haberle, P. Dwyer and R. Heinsohn answered numerous queries and provided previous sightings of harriers. Helpful reviews were given by A. Jenkins, K. Dutson, C. Symes and J.-M. Thiollay.

\section{References}

Baker-Gabb, D. J. (1986) Ecological release and behavioural flexibility in marsh harriers on islands. Emu 86: $71-81$.

Beehler, B. M., Pratt, T. K., and Zimmerman, D. A. (1986) Birds of New Guinea. Princeton: Princeton University Press.

Bell, H. L (1982) A bird community of lowland rainforest, New Guinea. Еmu 82: 65-74.

BirdLife International (2004) Threatened birds of the world. Cambridge, UK: Birdlife International.

Bretagnolle, V., Ghestemme, T., Thiollay, J. M. and Attie, C. (2000) Distribution, population size and habitat use of the Reunion Harrier Circus m. maillardi. J. Raptor Res. 34: 8-17.

Coates, B. J. (1985) Birds in Papua New Guinea. Vols. I and II. Port Moresby, Papua New Guinea: Robert Brown.

Coates, B. J. and Peckover, W. (2001) Birds of New Guinea and the Bismarck archipelago. A photographic guide. Alderley, Australia: Dove Publishing.

Corlett, R. T. (1984) Palynological evidence for changing subsistence patterns around Mt Wilhelm, Papua New Guinea. Singapore J. Tropical Geog. 5: 102-111.

Corlett, R. T. (1987) Post-fire succession on Mt Wilhelm, Papua New Guinea. Biotropica 19: 157-160.

Curtis, O. E., Simmons, R. E., and Jenkins, A. R. (2004) Black Harrier Circus maurus of the fynbos biome, South Africa: a threatened specialist or an adaptable survivor? Bird Conserv. Internatn. 14: 233-245.

Diamond, J. M. (1972) Avifauna of the Eastern Highlands of New Guinea. Cambridge, Mass: Publications of the Nuttal Ornithological Club, No. 12.

Diamond, J. M. (1985) Evolution of ecological segregation in the New Guinea montane avifauna. Pp. 98-125 in T. Case and J. M.
Diamond, eds. Community Ecology. New York: Harper and Row.

Ferguson-Lees, J. and Christie, D. A. (2001) Raptors of the world. Oxford, UK: Oxford University Press.

Flannery, T. (1995) Mammals of New Guinea. New Holland, Australia: Reed Books.

Gilliard, E. T. and Lecroy, M. (1961) Birds of the Victor Emanuel and Hindenburg Mountains, New Guinea. Bull. Am. Mus. Nat. Hist. 123: 1-86.

Gilliard, E. T. and Lecroy, M. (1967) Annotated list of birds of the Adelbert Mountains, New Guinea. Bull. Am. Mus. Nat. Hist. 138: 53-81.

Haberle, S. G. (1998) Late Quaternary vegetation change in the Tari Basin, Papua New Guinea. Palaeogeography, Palaeoclimatology, Palaeoecology 137: 1-24.

Haberle, S. G. (2007) Prehistoric human impact on rainforest biodiversity in highland New Guinea. Phil. Trans. R. Soc. B. 362: 219-228.

Haberle, S. G., Hope, G. S. and van der Kaars, S. (2001) Biomass burning in Indonesia and Papua New Guinea: natural and humaninduced fire events in the fossil record. Palaeogeography, Palaeoclimatology, $\mathrm{Pa}$ laeoecology 171: 259-268.

Hartemink, A. E. (2003) Soil fertility decline in the tropics: with case studies on plantations. Oxford, UK: CAB International Publishing.

Heads, M. (2002) Regional patterns of biodiversity in New Guinea animals. J. Biogeog. 29: 285-294.

Hoogerwerf, A. (1964) On birds new for New Guinea or with a larger range than previously known. Bull. Brit. Orn. Club 84: 94-96.

Hope, G, Tulip, J. (1994) A long vegetation history from lowland Irian-Jaya, Indonesia. 
Palaeogeography, Palaeoclimatology, $\mathrm{Pa}-$ laeoecology 109: 385-398.

Hornbuckle, J. (1997) The Baliem Valley. Pp. $174-175$ in P. Jepson and R. Ounstead, eds. Birding Indonesia, a bird watchers guide to the world's largest archipelago. Singapore: Periplus Editions and Birdlife International.

Johns, R. J. (1989) The influence of drought on tropical rainforest vegetation in Papua New Guinea. Mt. Res. Devel. 9: 248-251.

Kinnaird, M, and O'Brien, T. (1998) Ecological effects of wildfire on lowland rainforest in Sumatra. Conserv. Biol. 12: 954-956.

Kinnaird, M., O'Brien, T., Winarni, N., Iqbal, M. and Paoli, G. (2007) Rebounding from drought and fire: are ENSO events becoming too frequent for tropical rainforest recovery? Oral presentation, Society for Conservation Biology, Port Elizabeth, South Africa.

Legra, L. A. T. (2005) Nest-site selection and behavioural biology of the New Guinea Harpy Eagle Harpyopsis novaeguineae. Hons thesis, University of Papua New Guinea, New Guinea.

Legra, L., Li, X. and Peterson, T. (2008) Biodiversity consequences of sea level rise in New Guinea. Pacific Conserv. Biol. 14: 192-199.

McAlpine, J. R., Keig, G. and Falls, R. (1983) The climate of Papua New Guinea. Canberra: Australian National University Press.

Mack, A. L., and Wright, D. D. (1996) Notes on occurrence and feeding of birds at Crater Mountain biological research station, Papua New Guinea. Emu 96: 89-101.

Marsden, S. J., Symes, C. T. and Mack, A. L. (2006) The response of a New Guinean avifauna to conversion of forest to smallscale agriculture. Ibis 148: 629-640.

Mayr, E. and Gilliard, E. T. (1954) Birds of central New Guinea; results of the American Museum of Natural History Expedi- tion to New Guinea in 1950 and 1952. Bull. Am. Mus. Nat. Hist. 103: 317-374.

National Geographic (1990) Atlas of the world. Washington DC: National Geographic Society.

Rene de Roland, L-R., Rabearivony, J. and Randriamanga, I. (2004) Nesting biology and diet of the Madagascar Harrier (Circus macrosceles) in Ambohitantely Special Reserve, Madagascar. J. Raptor Res. 38: 256262.

Simmons, R. E. (2000) Harriers of the world: their behaviour and ecology. Oxford, UK: Oxford University Press.

Simmons, R. E. (2005) African Marsh Harrier. Pp. 501-502 in P. A. R. Hockey, W. R. J. Dean and P. G. Ryan, eds. Roberts birds of southern Africa. Johannesburg: John Voelcker Bird Book Fund.

Symes, C. T. and Marsden, S. J. (2005) Notes on breeding of Salvadori's Teal Anas waigiuensis and other birds in Crater Mountain Wildlife Management Area, Papua New Guinea. Bull. Brit. Orn. Club 125: 11-27.

Timmerman, A., Oberhuber, J., Bacher, L., Esch, M., Latif, M. and Roeckner, E. (1999) Increased El Nino frequency in a climate model forced by future greenhouse warming. Nature 398: 694-697.

Westerling, A. L., Hidalgo, H. G., Cayan, D. R., and Swetnam, T. W. (2006) Warming and earlier spring increase western US forest wildfire activity. Science 313: 940943.

Whitmore, T. C. (1984) A vegetation map of Melanesia at a scale of 1:5 million. J. Biogeog. 11: 461-471

Young, D. J., Navarro, R., Anderson, M. D. and Colahan, B. (2003) Big birds on farms: Mazda CAR report 1993-2001. Cape Town: Avian Demography Unit, University of Cape Town.

\section{ROBERT E. SIMMONS*}

DST/NRF Centre of Excellence, FitzPatrick Institute, University of Cape Town, Rondebosch 7701, Republic of South Africa. Present address: Dept of Nature Conservation, Tshwane University of Technology, Pretoria ooo1, Republic of South Africa. 
LEO A.T. LEGRA

Wildlife Conservation Society, P.O Box 277, Goroka, Eastern Highlands Province, Papua New Guinea.

*Author for correspondence: e-mail; Rob.simmons@uct.ac.za

Received 9 July 2008; revision accepted 1o December 2008 